\title{
“IT'S SO LITTLE MONEY YOU COULD MAKE AS MUCH AT HOME" OPTIONS FOR WORK IN AN IMPOVERISHED RURAL REGION OF HIGH UNEMPLOYMENT ${ }^{1}$
}

ILDIKÓ HUSZ ${ }^{2}$

\section{INTRODUCTION}

Hungary has a higher unemployment rate than the member states of the European Union and even most former socialist countries. This rate for 15-64 year-olds has been around 56\% since 1999, as against 66\% in the European Union (OECD Employment Database). There is also a high degree of regional unevenness within the country. The situation is worst in North Hungary, an area of multiple economic and social deprivations.

Several pieces of research have analysed the causes of long-term unemployment and have highlighted the main social, geographical and institutional factors behind it. People of low educational attainment who live in small villages and members of the Roma minority are particularly likely to have been without jobs for a long time.

In 2007, a demographic survey of small villages in North Hungary collected data about 15-49 year-old women who had not received upper secondary school achievement certificates. This survey was followed up by life-course interviews with persons selected from the sample. The original purpose of the survey was to identify patterns and ethnic-specific elements which related to how people living in poverty bear children and start families. As the data was

1 The research was supported by OTKA (Ref. No. PD78513) and the European Social Fund (TÁMOP-4.2.2/B-10/1-2010-0023).

2 The author is senior research fellow at the Hungarian Academy of Sciences, Centre for Social Sciences, e-mail: husz.ildiko@tk.mta.hu 
processed, employment rates were found to be even lower than expected: the respective rates of employment for Roma women and their partners in the sample were just $6 \%$ and $35 \%$ - compared to the national averages of $20 \%$ and 38\%. ${ }^{3}$ The figures were also lower for the non-Roma subsample; $36 \%$ and $56 \%$ respectively. Most of the interviewees were long-term unemployed, and many of them, especially women, had never had permanent jobs. This fact prompted further study into what local factors are behind this very low rate of labor market participation.

The study described here draws on qualitative research to present the local factors which hinder and support the seeking of work and examines how, when individual make decisions about whether to accept work. These factors interconnect to create an alternative employment system to the open labor market. This market finds expression in the high rate of unemployment at a macro level. We also briefly consider some related ethnic differences.

\section{CAUSES AND CONSEQUENCES OF LONG-TERM UNEMPLOYMENT - A REVIEW OF THE LITERATURE}

The emergence of long-term unemployment can only partly be explained by the post-transitional economic recession. More precisely, we can say that economic restructuring at the time of the political transition rendered long-term unemployment visible; it already existed in the previous system but was kept "within the factory gates" to satisfy the political objective of having full employment. In the 1990s, as industrial companies closed down or were reorganised to become competitive and agriculture fell into crisis, large numbers of people who lacked up-to-date skills were cast on to the streets. A lack of an appropriate educational background and skills remains the main reason for the long-term unemployment which has persisted ever since. People with no more than a primary school education have suffered the greatest displacement from the labor market. In the mid-2000s, women in this group were $29 \%$ less likely and men $25 \%$ less likely to be employed than their counterparts with secondary school leaving certificates (Köllő 2009).

The labor market position of Romas has suffered a greater-than-average deterioration. A 2003 national representative survey of Romas found that only $38 \%$ of Roma men and $20 \%$ of Roma women between the ages of 15 and 49 were employed, compared with respective figures of $85 \%$ and $53 \%$ at

3 National figures are based on the Roma survey which took place in 2003 (cf. Kertesi 2005). To ensure comparability of the results, pensioners and students are excluded. 
the time of the political transition (Kertesi 2005). The disadvantages show up in both the loss of jobs and in the lack of opportunities to find new jobs. The opportunity gap is due largely to the average level of education of Roma and to a lesser extent to discrimination against Roma workers. The latter factor was found to be particularly relevant in the early 1990s during the first stage of the transition (Kertesi 2005).

The rates of participation in the labor market differ by region as well as by level of education and ethnic group: this rate is $60.2 \%$ in the wealthier central part of the country and $48.7 \%$ in the more deprived Northern Hungarian region (KSH Stadat). The crisis primarily hit settlements where the main source of employment in the past was socialist heavy industry, whose plants closed down one after the other in the 1990s. In depressed areas the composition of the labor supply (the high proportion of uneducated people) and inadequate infrastructure inhibit modernisation of the inherited economic structure. The latter is particularly problematic in areas surrounding small villages where difficult access to jobs and the high cost of commuting are in themselves deterrents to taking a job (Köllő 1997, Kertesi 2000, Bartus 2007).

Some research has found that while a loss of jobs for the unskilled was a natural concomitant of the formation of the market economy in the posttransition years, persistent unemployment is characteristic of Central and Eastern European countries. A contributory factor is the lack of small and family businesses which, in wealthier countries, play a major part in employing uneducated workers (Köllő 2009).

Government measures have proved incapable of remedying the employment crisis. Demand for unskilled workers is dampened by the relatively high minimum wage (Kertesi-Köllő 2004, Köllő 2009). On the labor supply side, neither the frequent changes to the benefits system nor public works programmes have provided sufficient incentives for the return of the longterm unemployed to the open labor market (Bódis et al. 2005, Tardos 2005, Csoba 2010, Balás et al. 2011). The child benefit system has a further effect of encouraging mothers to stay at home (Bálint - Köllő 2008).

While the research mentioned so far has investigated the structural and institutional reasons for low employment levels, local studies have focused on the cultural basis of adaptation to long-term unemployment. Such research has sought to determine the survival strategies adopted by poor people. Since the Roma are disproportionately highly represented in this stratum of society they have been the primary focus of empirical studies. The research has attempted to identify the processes by which Roma have been displaced from the labor market in the long term. In this regard, several pieces of research have reported on their efforts to make up for lost wage income and various 
remunerative activities and survival strategies (Tóth 1997, Fleck-Virág 1998, Szuhay 1999, Kemény 2000, Durst 2002, Virág 2008, Havasi 2010, MessingMolnár 2011). Despite the diversity of these publications they paint a fairly uniform picture: return to the formal labor market is not a realistic alternative for the long-term unemployed Roma, for whom the various forms of welfare benefits have become main sources of income. In addition, it is common for them to take up casual and/or seasonal work in the informal sector and other remunerative opportunities.

This strategy for making a living employed by the Roma cannot in fact be linked to the post-transition employment crisis. In the early 1980s Gábor Havas wrote of a "jack-of-all-trades" lifestyle which relied on gathering/ trading for generating income. This approach takes advantage of short-term economic openings and is more attractive than the "company employment" on offer. This form of existence emerged in response to the decline in demand for the Romas' traditional occupations rather than to the contraction of the formal labor market, and enabled local communities to adapt to their enforced changes in occupation while retaining the essential elements of their old, itinerant life (Havas 1982). This finding chimes in with anthropological descriptions about how traditional Gypsy culture promotes an aversion to the world of the wage system and adherence to forms of activity that fit better with Gypsy value systems (Okely 1983, Stewart 1994, Formoso 2000). As a result, the employment crisis which hit at least part of the Roma community in the late 1980s did not lead to a new lifestyle but rather to alterations in the structure of previously-existing sources of income (it greatly reduced income gained from the primary labor market and raised the significance of welfare benefits). This was no doubt accompanied by the rising intensity of other income-generating activities, but we have little information about this. For groups more closely linked to the wage-work sector, however, the closure of old industrial factories which had provided mass employment presented a more serious challenge.

The extent to which the ways of making a living, outlined by the local research (above all, a dependency on benefits) may be regarded as rational responses to limited opportunities or as cultural patterns of adaptation is disputed, as is the question of whether ethnic culture or a culture of poverty was at work. Arguments supporting the latter are based on the fact that many of the activities formerly regarded as "ethnic" may also be undertaken by poor non-Roma (Havasi 2010, Messing-Molnár 2011). Some opinions go further; e.g. Lewis (1961) in identifying the distinctive lifestyles and habits of the Roma as being the consequence of a status of persistent exclusion, a culture 
of poverty ${ }^{4}$ with a kind of relative autonomy, itself contributing to long-term unemployment and thus the regeneration of poverty (Ladányi - Szelényi 2004). The outcome of the debate, especially as regards the rationality of modes of adaptation, is not without lessons for government policy because it can determine the effectiveness of employment, family and social policy measures that affect the parameters of decisions.

\section{STUDY SITE}

The qualitative research described in this paper was carried out in the highunemployment villages of the subregions around Edelény and Encs in the north of Borsod County between June 2008 and June 2009. ${ }^{5}$ There are two towns in the area (Miskolc and Edelény) with substantial job potential for people living in the surrounding villages. Miskolc is the primary centre of attraction by virtue of its size while Edelény is a secondary job-market centre. The villages studied lie 34-66 km from Miskolc and 20-50 km from Edelény ${ }^{6}$.

About one third of Hungary's Roma population lives in the north of the country and is concentrated in a few multiply-deprived subregions. The site of our study corresponded to two of these sub-regions, so the Roma population was highly over-represented compared to their population in the rest of the country. It is mainly Romungros (Hungarian speaking Gypsies) that live here, with a minority of Vlach Gypsies. Hovewer, the local system of categorisation does not correspond to the ethnological-anthropological categories. The main lines of distinction are between Romas ("Gypsies") and non-Romas ("peasants"), and Roma groups or communities are distinguished by their place of residence ${ }^{7}$. The term "Vlach Gypsies" was used mostly by "peasants" and refers to those who are regarded as boisterous and violent.

Local people - Roma and non-Roma - distinguish between groups of Romas on the basis of where they live. They speak of the "good Gypsies"

4 In the community they studied, Ladányi and Szelényi considered extreme egalitarianism, lack of respect for authority and short-term attitudes to be the main features of the culture of poverty (Ladányi - Szelényi 2004).

5 On societies of the villages in the region, see Havas (1999) and G. Fekete (2005).

6 These distances from Miskolc and Edelény are distances by car. In the case of Edelény, longdistance buses take longer routes.

7 Locality-based differences among Borsod Gypsies have been examined in connection with childbirth by Durst (2006). Szuhay also highlights the local character of Gypsy culture which they report to be in a "state before cultural homogenisation" (Szuhay 1999:11). 
from village $\mathrm{X}$ and those from village $\mathrm{Y}$ who reportedly embody all the stereotypes commonly associated with Gypsies: vulgar, dirty, lazy, living on benefits and child support. If a family moves from $Y$ to $X$, they are viewed by the locals with mistrust and apprehension. Despite the limitations of the Roma marriage market, given their ethnic isolation, residents of $\mathrm{X}$ have a reluctance to seek marriage partners from area Y. The location has no significance in itself in the categorisation but simplifies the labelling. The recurrence of surnames suggests that each village has a few blood-related groups (clans) of common origin, with their own norms and lifestyles that mark the boundaries of the group within the community. ${ }^{8}$ Even after a clan breaks up and some families move out of the village, common norms and customs are preserved in the form of local identity. Most of the Roma interviewees were from two "X-type" villages (i.e. with "good Gypsies"), one with a high level and the other a lower level of ethnic segregation.

The families of poor non-Roma residents of low educational attainment, unlike the Romas, tended to be scattered through the village rather than being grouped together. The interviewees were thus drawn from seven neighbouring or close-by villages.

Fieldwork consisted of life-course interviews and in some cases group interviews and involved a total of 40 people. The interview subjects were selected from the earlier survey sample and so our findings do not apply to the population of the region as a whole but to poor village people of low educational attainment. In some villages, particularly those where the majority are Romas, practically the entire population belongs to this category. Elsewhere there are some smallholders and employees whose financial position is relatively stable. The emphasis should be on "relatively": neither farming nor a permanent job are paths to wealth here, but these families do at least have some reserves to get them through crises such as bad harvests or the loss of a job. People who have raised themselves out of poverty have already moved out of this permanently crisis-ridden region.

The respondents were mainly 20-50 year-old women but questions about the labor market also yielded information about the male family members and the village as a whole. Our interviewees, and usually their partners (husbands or cohabitees), did not have upper secondary school leaving certificates and their job prospects were therefore greatly restricted. Nowadays, it is the upper secondary school leaving certificate rather than a trade qualification which is the crucial factor in finding a job.

8 See Romano Rácz's (2008) paper on this phenomenon in a Nógrád County village. 
Certain factors which acted as incentives and disincentives to seeking employment were frequently mentioned and were regarded by interviewees as being typical. These factors will be discussed first.

\section{LABOR MARKET INCENTIVES AND DISINCENTIVES}

The labor market in the region is largely the legacy of the pre-transition period. Having long been employed in the large and medium-sized state industrial enterprises which operated in the area before the transition, many people in the region found it hard to adapt after these operations closed down. The working culture of large enterprises ${ }^{9}$ did not nurture the initiative required for successful adaptation and entrepreneurial propensity did not increase after people were made redundant. The evidence of this is that the number of small and medium-sized enterprises relative to population in this region is still among the lowest in Hungary (KSH Stadat). Exacerbating the crisis, many local production cooperatives closed down during the 1990s, causing a parallel decline in the number of agricultural-sector jobs. Low farm gate prices destroyed the agricultural activity which formerly took place on family plots of land, which was once an important supplement to income. Very few people in the villages of the region produce more crops or animals than meet the family's direct needs nowadays. Regular cash income therefore primarily consists of state transfers. These are not enough to live on, and so people try to supplement them through undertaking various forms of activity.

\section{Demand on the formal labor market - where can you find a job?}

The interviewees were unanimous about their being no jobs for either men or women in their own or in nearby villages. It is true that the only employer in most villages is the council which is responsible for providing jobs in public offices, the school and the nursery. Local labor demand, especially for people of low educational attainment, is very weak and out of all proportion to supply. For most of the village population working locally is thus not an option: if somebody wants a job, they will have to commute.

The larger employers are based in towns. Two types of patterns of commuting are common in the region: a minority of those with regular paid

9 For the connection between former work in large enterprises and low entrepreneurial propensity in Hungary, see the review by Kopasz (2007). 
work travel to Budapest once or twice a month, and the majority travel every day to Miskolc or Edelény or to other local towns. Most unemployed people consider the attractive jobs to be into the latter category (reachable by daily commuting) since previous bad experiences with working in Budapest and the high cost of living discourage many of them from even considering looking for work there.

"The truth is, if you go and work in Budapest, if you don't go to a real job, but some kind of private outfit, there is a risk whether they'll pay or not. A lot of them have the nerve not to pay. And then you have to have enough to live for a month. Then there's the travel, and that's so expensive it's just not worth it. All that for about 20 or 30 thousand forints in your hand, you won't have any more left anyway. It's not worth it. The truth is, it's so little money you could make as much at home, and you could stay at home."

In Miskolc there are a range of job opportunities for unqualified people but in Edelény regular work is to be found only in the chocolate factory, the concrete factory, to a limited extent the hospital and a few industrial and other small enterprises.

\section{Incentives to seek work - how much can you earn by commuting?}

The general view was that jobs in towns within commuting distance usually pay the minimum wage which is not enough to make it worthwhile shouldering the high costs of commuting. At the time of the survey, the Hungarian minimum salary was HUF 71,500, which leaves HUF 58,000 net after taxes and deductions. ${ }^{10}$

"The mines have closed, the agricultural cooperatives have been wound up. Private companies are only going to pay the minimum wage, and they don't give you a bus pass. So if you go to Miskolc to work for the minimum wage and the bus pass is 20,000 forints, what do you have left? People who weren't made redundant then, in the early '90s, still go away and work, but not many others."

10 Interviewees always talked of "take home pay", so that is what figures in interview excerpts refer to. 
Earning the minimum wage is therefore not an attractive prospect, and everybody who once had a job reported receiving higher pay than this. The amount of reservation wage ${ }^{11}$ depends on the distance to the working place and the type of employment. A monthly income of 100,000 forints was mentioned several times as a kind of psychological threshold above which it was worth travelling even further to work (Budapest, even abroad), but comments in the interviews made it clear that such opportunities are only found in the shadow (grey or black) economy ${ }^{12}$. Working for any less than this was only worthwhile if it provided some kind of long-term security and official status. There are very few such opportunities.

"My husband drives a tractor for the ... company here. It's a permanent job, officially registered. He takes home 81,000 forints... They work eight hours. Sometimes more. If he works longer, he might get a day off, because they don't pay overtime. Until now at least they paid, but now they don't pay either."

The poor labor market positions of interviewees means that they have difficulty in more than just finding work, receiving low wages and working in poor working conditions; it also shows up in job instability. A person is fortunate if they can work in the same job for more than a few years. As Éva Havasi put it, most people living in poverty are "regular casual workers" (Havasi 2010:46). Gábor Kertesi considers employment instability to be characteristic of the labor market position of the Roma and his figures show that it is not characteristic of employment among non-Romas with low qualifications (Kertesi 2005). Our own field observations contradict this: the time spent by members of poor families from the deprived region employed in one job was short, regardless of their ethnicity. It should be noted that the poorest members of village society have experienced this kind of employment uncertainty in other periods of history (as servants, day-laborers or sharecroppers, for example), and it is in this light that their job security during the few decades of socialist heavy industry should be assessed.

11 The reservation wage is the lowest wage rate at which a worker would be willing to accept a particular type of job.

12 This refers to payment without tax, or taxation on earnings up to the minimum wage and untaxed payment above this level. 


\section{Commuting costs}

There have been several studies about the disincentive effect on the labor market of high commuting costs (Köllő 1997, Kertesi 2000, Bartus 2007). This problem is particularly marked in the region we studied. ${ }^{13}$ The villages in the survey were a one or one-and-a-half hour's bus journey from the larger towns. Most of the commuting costs go towards purchasing the longdistance and municipal local bus passes which cost between HUF 20,000 and 40,000 , depending on distance. The law requires the employer to reimburse commuting costs. In practice, companies have no interest in paying for bus passes because they can usually find labor locally. Respondents agreed that employers would pay for a bus pass for up to $20 \mathrm{~km}$, but above that they would only pay half of all travel costs, or would not employ commuters at all.

"In Borsod at least there's no work anyway. I've heard from quite a few people about going there and there trying for a job. They ask right off, are you local? If you say no, then it's sorry, the job's filled, and that's it. They're sent away. Never mind that they haven't got anybody, they send you away so that they don't have to pay for your travel... There's no more of wherever you go to work, they buy you a pass or pay you back if you buy it. They pay for about 20 kilometres, then it comes out of your own pocket."

In some villages commuting is impossible because of "employment unfriendly" long-distance bus timetables. Most jobs which are offered to unqualified people start at 6am, but the bus company's timetables are mostly aligned with school timetables and schools start at 7.45 or $8 \mathrm{am}$. These jobs can only be taken by people with cars, which makes commuting very expensive. At the time of the survey, the monthly fuel cost of going to work every day (travelling a distance of $40 \mathrm{~km}$ ) was about 35,000-40,000 forints, an amount which would be worthwhile paying only in return for a wage that was high by local standards.

"... if there was a bus service. But you can't get anywhere for 6 from here, because the bus to Miskolc leaves at nearly 5 o'clock, which means you're in Miskolc by a quarter to seven. And what company will let you go to work at 7 if others are there at $6 ? "$

13 Gábor Kertesi, in one of his studies, published a map of villages worst placed for commuting. All of the villages studied here fall into this category (cf. Kertesi 2000). 


\section{Alternative work: seasonal work and state-subsidised employment}

The lack of jobs within reasonable proximity has led to peculiar combinations of making a living in recent times. Through the public works programme the local authority gives minimum-wage employment to most village residents who are unemployed but capable of working. In order to disseminate public works jobs to as many people as possible each employment contract usually lasts for 3-4 months, and longer periods are rare ${ }^{14}$ At the end of this period regular income for the rest of the year will be in the form of social benefits ${ }^{15}$ which are usually HUF 20,000-30,000 less than the net minimum salary. The difference (of approx. HUF 160,000-270,000 yearly) plus some more, can be earned from seasonal and ad hoc casual work, which mainly available from March to early December.

There is quite a wide variety of seasonal and casual work. It includes mushroom-picking, herb-collecting and snail-collecting (the produce being sold to traders who come to the village), fruit-picking on a day-labor basis in local orchards, mowing, haymaking, hoeing, woodcutting and other household work. Anybody with a car can also earn money by providing transport. Work for laborers and tradesmen with small contractors has fallen off perceptibly in recent years as those who would employ them have also become impoverished, although the proximity of the Slovak border and Slovakia's accession to the European Union has created new opportunities. Abandoned houses in villages on the Hungarian side of the border are being bought by Slovaks who employ local tradesmen and workers to refurbish them. There is also some demand from other side of the border for blackeconomy labor in the construction industry. The interviewees said that there was work of this kind throughout most of the year for anyone who wanted it. This is of particular significance during the winter months when there is no agricultural seasonal work.

14 The situation is similar in some private companies (such as the nearby chocolate factory) where labour is hired via the local employment centre. According to the survey respondents, the typical period of employment is also only a few months; the period the employer is entitled to receive state subsidies for the employee.

15 The names of regular monetary benefits for persons of active age but who are not in work have changed frequently in recent years. Most of the interviewees simply used the word 'segély' (benefit) to refer to what are officially called "regular social benefits" and "availability support". 
"There are so many people in the village I could tell you about who never get a job because for that money it's better for them to sit at home. ...They're at home, and they can do as much black work as they want. ...And they still get benefits. And they're here all day."

"I get child care allowance and family allowance, and he (husband) gets an availability allowance and we are lucky that all year there's always something we can make money from, like now it's the mushroom season. You can make a lot from that... You can pick flowers (herbs). Then there will be rose hips, sloes, crab apples, wild pears. So from spring right up to late autumn you can always make money with something."

Prices paid for produce and day-labor rates vary widely depending on the harvest, the season and the difficulty of the work. From what respondents said, daily income varies from about HUF 2-3000 to HUF 10,000, and anything above 4-5000 is considered good. The difference between the minimum wage and the amount which can be collected in benefits can be earned in 4 -7 months with only 10 days of work a month and an average daily income of HUF 4,000 .

"When there's a good season, a week or two, if there are lots of mushrooms, you can make 70 or 80,000 forints. In spring, when we started in March, it (mushroom picking) went for a month, and we must have got 100-120,000. 6 or 7000 forints a day, or 5000. When there was very little, then 2 or 3000. You can also make 10,000 a day from camomile."

"The gang I went picking with don't even want to come peach picking... for them the 2300 forints (a day) is nothing. I said, lucky for them. Because they have a 50\% disability allowance. It's not much, but they get some (disability allowance). But for me even 2300 forints is something, because I don't get anything. ...Because whoever can go, and wants to, can get this casual work, certainly now that the Slovaks are coming, they need laborers for roofs and plastering, and some take it, but some say not for that money. I'm going to get 2300, and I'll go, because for me 2300 is money."

Seasonal work is complemented with work on family plots of land. The vegetables and animals (mainly poultry) that respondents produce are only 
for their own consumption. It is rare that they sell any of it, only when the quantity of produce is above average.

Several recent studies have stressed that the public works programme is not helping workers escape the social benefits system. This finding is reinforced by our own field observations: the main source of income for poor village families nowadays is a combination of public works, social benefits ${ }^{16}$ and seasonal and casual work. It is important to note that these activities are also functionally interconnected and form a system of making a living that is an alternative to the usual world of wage work. Its system-like character contributes to the permanence of respondents' isolation from the formal labor market. Public works make one eligible for social benefits but also allow access to seasonal and casual work. The staff of the local mayor's offices are also aware of the role of these activities in contributing to family income, and even if they do not explicitly coordinate public works with seasonal work they may tacitly tolerate it through supervising it only loosely.

This is shown in the following case when in the absence of a village mayor his deputy had to take over direction of people employed in public works. When he checked he found that several of them were absent without permission during working hours. It later turned out they were working in the orchard of a local land owner. The fruit had ripened all at once and there was (black) work for a lot of people. The deputy mayor, who was not born locally and who grew up in an urban environment, immediately dismissed these people, provoking disbelief from both the people concerned and other people in the village who were used to a more tolerant attitude in these cases.

Seasonal work plays a part in the life of village families which should not be underestimated. It is a permanent and relatively predictable form of work. In addition, work of a few days or maybe one or two weeks brings an immediate cash income, in contrast to the monthly payments which are usual in the world of 'normal' employment. In the socialist era, local state enterprises adapted to the seasonal labor demands of small-scale agricultural work by turning a blind eye to short working days and more frequent days off during the harvesting season but in today's market economy employers are not so tolerant. By contrast, the public works programme, besides its socialisation function in keeping people in work, allows the opportunity to be engaged in seasonal work, thus boosting family income.

16 Locals also usually refer to "availability support" for the unemployed as "social benefits". 
All the signs are thus that the trinity of public works, casual work and social benefits is a realistic alternative to employment on the primary labor market, at least in the short term. Since this method of earning a living does not entitle individuals to a pension and the income it provides does not permit a significant amount of money to be saved, the question remains: how will these people live after they are past normal working age? The question did not seem to concern the people who live here as much as might be expected. They hardly mentioned any concern in this regard. This is partly related to their generally poor state of health which female respondents worried about in particular. Even mothers in their early ' 40 s frequently complained about illnesses that prevent them from working or restrict their potential for work. This poor outlook is borne out by national statistics: the life expectancy at birth for women in Borsod County is a year and a half shorter than the national average and for men it is two and a half years less (KSH 2010b).

"Will I be working in five years' time? Oh, in five years time I might not even be living. I've been sick for years. I've got inflammation everywhere, my arms, my joints. I've got high blood pressure, heart disease... Five years, that's an awful long time, I don't know whether I'll live that long." (43 year-old woman)

From this perspective, having a short-term outlook does not seem excessively irrational. Present advantages are favoured over uncertain future benefits, such as the small pensions that they might, in theory, look forward to.

\section{ETHNIC DISTINCTIONS AT WORK}

Ethnic differences at work in the region can be traced back to three factors: cultural features that lend certain kinds of work an ethnic character; veiled discrimination against Roma workers; and the lower employment rate of Roma women because of the high number of children they typically have.

Research on the lifestyle of the Romas has established a correlation between ethnicity and several occupations (see Erdős 1958, Havas 1982, Stewart 1994, Fleck - Virág 1998, Szuhay 1999, Horváth 2002, Havasi 2010, Messing - Molnár 2011). In the villages included in this study, occupations of this kind included gathering produce for sale, a category of seasonal work done particularly often by the Roma. Their predilection for collecting wild produce probably arises from the relation between income and individual abilities such as resourcefulness and speed. In the mushroom season it is almost a 
contest to see who can get up earliest and get out to the forest because this largely determines how much they can "bag". The location of good sites is kept secret and is not divulged, even to strangers like us. Actually selling the produce, i.e. making a business out of it, is of lesser importance because prices are set by buyers. ${ }^{17}$ Loan-sharking as an occupation seems also to take place in Roma communities but involves very few people. Growing vegetables and keeping animals on family plots of land, however, are activities mostly confined to non-Romas. ${ }^{18}$ This is why non-Romas, using the village system of categorisation, are termed "peasants", although in social historical and enthnographic terms a large proportion of the population in these villages are of agricultural laborer origin.

Another type of ethnic distinction in work is the consequence of various means of social exclusion. Using the categories specified by Loury (2006), a variety of formal and informal methods of discrimination could be identified from the respondents' stories. They go beyond Roma narratives about how employers reject otherwise-suitable applicants for jobs on racist grounds. ${ }^{19}$ Such stories were rarer than was expected; in fact, sometimes - for example in connection with the pointlessness of further education - interviewees stressed the narrowness of gaps in local society by insisting that there were no job opportunities in the area regardless of ethnic origin (or qualifications).

A peculiar type of social exclusion based on ethnic stereotypes shows up in a story we heard from the head teacher of a school. To make the school canteen more economical, there is a prepaid lunch system for local residents, in which the school has a financial interest. A Roma woman was taken on to wash the dishes but shortly afterwards had to be dismissed. The people in the village did not consider her to be sufficiently clean and told the head teacher they would not order meals from the kitchen if she continued to work there. The head teacher - not a local-

17 Often it is not so much occupations but the way of carrying out activities that has an ethnic character. Classifications of the kind "Gypsies do it like this, peasants like that," make the same kind of contribution to constructions of race as "identity-forming" occupations and ways of making a living (See also Horváth 2001).

18 Based on field work, some researchers have reported about villages where Roma families follow more or less peasant-like ways of life (i.e. they cultivate land and keep animals) but these are considered unique rather than general cases. (Szuhay 2005, Durst 2006).

19 Racial stereotypes can be created by Romas themselves and are not only used against them. The usual stories of labour-market discrimination, regardless of their truth, are to some extent driven by a stereotype of the gadjo employer who does not like Roma. 
born person - considered the accusations to be unjustified but dismissed the women out of financial concerns. The symbolic meaning of "cleanliness" and its role in the designation of ethnic boundaries also arose in the story of a Village Day organised by Romas. To ensure that "peasants" would also take part in the event, the Roma engaged a non-Roma woman to do the cooking. ${ }^{20}$

The role of informal discrimination in job-seeking is also significant. Better, more desirable jobs are usually acquired using informal connections and these connections tend to lead to the formation of separate networks based on ethnicity. Information about opportunities for work normally reach the "other" ethnic group only when there is mass employment.

Neither is there equality of opportunity in the terms of employment contracts. One such (formal) discriminative practice occurs with the allocation of places for public works jobs. It is more than a matter of to whom the local authority gives work, for how many hours and for what duration. The months of the year in which the work is allocated are, as we have seen, also crucial. Least popular is summer, when there is an abundance of seasonal work. Most popular is winter, when the availability of alternative remunerative activity dwindles. As became clear from the interviews, Roma respondents were mainly employed in summer and autumn.

Low expectations about pay, high commuting costs, poor transport infrastructure and alternative earning opportunities keep workers of both sexes away from the formal labor market. For women, however, there are other factors which must be considered when taking up employment. These factors are mostly associated with raising children, which sets the basic context for a discussion of female employment.

There is a relatively high rate of fertility in the region: compared with a national total fertility rate of 1.3 , the figure for the two sub-regions studied is around 2.0 (Husz 2011). The number of children born to the women with low educational qualifications involved in the questionnaire survey was even higher: the completed fertility rate was 4.0 for Roma and 2.7 for the nonRoma. Regarding prospects for employment, a high fertility level results in early and long-lasting inactive periods in a women's life.

The first child was usually born within a short time after leaving school; in fact Roma girls were frequently absent from school because of their

20 For cultural differences in the meaning of cleanliness see Okely 1991, Horváth 2002 
pregnancies. Most interviewees, regardless of ethnicity, did not work between the birth of one child and the next. ${ }^{21}$ Whoever was capable started looking for a job when their youngest child reached school age (older children could be entrusted with the supervision of small children or taking them to nursery). With three children, maternity and childcare benefits permit a mother to stay at home until the youngest child is 8 years old, which means an absence of least ten or twelve years from the labor market. For Roma women (who have more children) this period is even longer. Since there is a high incidence of bad health or chronic diseases in childhood with families of both ethnic groups, mothers are often obliged to stay at home even longer. Nonetheless, respondents reported feeling obliged to go to work, not to stay at home (at least the interviewees were full of "musts" in that regard).

The statement that mothers of young children do not work only applies to involvement in the regular job market. The raising of children can be reconciled with various kinds of seasonal work, especially tending gardens and picking fruit in local orchards. These kinds of activities are done mainly, if not exclusively, by women.

The material burdens of caring for small children are alleviated by various kinds of family benefits, so having children does not result in a drastic change in the financial situations of families overall. Child benefit frequently changes in type and amount. When this research was conducted, such benefits included GYES, GYED and GYET ${ }^{22}$, various allowances related to schooling (maternity support, regular and non-regular benefits) and a family allowance. The latter carries the most weight in the family budget, the amount being greater for a family with four children that a single person's net minimum salary. ${ }^{23}$ It is thus understandable that, as has been reported in several studies,

21 From the birth of the first child to time that they go to school, the key question concerning the employment of women is day-care for children. Villages in the region are extremely badly-off in this respect: there are no crèches (for the under-3s) and nurseries exist only in a few larger villages and in the towns.

22 GYES (child care allowance): is a non means-tested child care benefit for children under 3 years old. GYED (child care fee) is a job-related maternity allowance for children up to 2 years old. GYET (child raising support) is a non-means-tested benefit for parents of at least three children (of whom the youngest is between 3 and 8 years old).

23 Mothers of several children are often accused of giving birth just so they can receive child benefits. This was mentioned by interviewees from both ethnic groups who had two or three children. It is a statement not borne out in respondents' life stories, since bearing a large number of children seemed to be more of a situative than a strategic response. Nonetheless, the state transfers and benefits for which large families are eligible undeniably have some influence on the number of children that are born. Receiving the family allowance alone, however, would not be enough to support this large number of childbirths if there were not 
Roma mothers of 5 or 6 or even more children derive special prestige from being recipients of this regular and predictable source of income. It is a widespread view that these benefits are the mother's contribution to the family (See also Kóczé 2010).

Since child-related benefits increase with the number of children and decrease in relation to their age, the question of finding work tends to arise when the smallest child goes to school or GYET expires. The factors behind any decision to find work are the same as for those in other circumstances: the potential pay and the cost of commuting. There is another factor, however, for women who remain responsible for traditional household tasks (housework, cooking, looking after children); this is the length of time they would have to spend away from home. ${ }^{24}$

"The closest job would be in the Edelény chocolate factory, where you have to leave at half past four in the morning, and you get home at 4 in the afternoon. If there's no grandmother, nobody can manage that."

\section{SUMMARY AND CONCLUSION}

This study used interviews to explore the local factors involved in the persistence of large-scale unemployment in a multiply-deprived region of Hungary. We were interested in the extent to which sustained absences from the formal labor market are based on rational considerations.

Our results show that the high unemployment rate is not solely a matter of a lack of jobs. The costs and benefits of jobs are very much assessed on the basis of deliberate economic calculations. The unanimous opinion was that, for people of low educational achievement, the costs of taking employment on the legal labor market (particularly the time and money involved in commuting) were so high at the time of our study that it was not worth working for the income that the job could be expected to generate (i.e. the minimum wage). In addition, jobs in the post-socialist economy do not even offer the advantages of stable employment. Instead of the world of "regular casual work" of the primary labor market, the vast majority of the economically active uneducated

also a supportive culture.

24 In an interview-based study in sewing workshops in eastern Hungary, Bódis also found that the traditional division of household labour between the sexes hinders work by women (Bódis 2002). Women get most help from older children than their husbands. 
population in the area are engaged in an alternative system of work comprising of the triumvirate of public work, participation in the shadow (black and grey) economy and receiving social benefits. The stability of this mode of earning a living derives not only from the opportunity if offers to gain a net annual income equivalent to that attainable through legal employment. Just as important is that the various ways of making an income are mutually permissive and complementary and form a kind of system. Moreover, this system permits more flexible organisation of work than a traditional full-time job would and thus better fits with day-to-day fluctuations in the working needs of village families.

The sober calculations behind decisions about whether to take up work and the continual seeking and flexible exploitation of alternative opportunities are signs of adaptive skill. Our respondents, who officially count as being unemployed, often appeared in the interviews to be disillusioned, embittered and disappointed, but not hopeless. Rather than a culture of poverty, their case suggests a rationality of poverty. This of course does not imply that the world of work is not culturally embedded. It does, however, manifest itself in the repetition of historically-established cultural patterns, where adaptation means selecting from among the local traditional activities and arrangements ${ }^{25}$ which people have known since their childhood or have learnt from the experiences of their parents. Certain ethnic factors were also observed and manifested themselves in ethnic (or perhaps only ethnically-linked) labor market characteristics. Evidence of an autonomous culture of poverty, as put forward by Lewis and his followers, involving a kind of desperate, selfdestructive fatalism, was certainly not widely in evidence.

A question arises: what are the options for public policy that would encourage employment and boost the pension contributions? The present approach (reducing and/or maximising the amount of benefits which are given), is designed to weaken the disincentive to work. The raising of the minimum wage at the same time, although it should in theory act as an incentive to work, further reduces the number of jobs on the primary labor market and will probably expand the size of the shadow economy. It is not clear how workers will react to these changes - whether they will increase their efforts to find legal work or whether they will intensify their activities

25 This refers to the observation that interviewees did not usually seek a way out of their predicaments through starting any kind of (small) entrepreneurship which was foreign to the traditional role of agricultural impoverishment. In the past, leading a 'peasant' way of life similarly had no cultural precedent in Roma communities and failed to take root, despite many well-intentioned experiments to encourage it. 
in the black or grey economy. For the people living in these villages, living conditions will only improve in the short term if the process of job seeking is facilitated and in the long term only if the creation of legal and 'real' - i.e. not public work-related - jobs is promoted. This would coincide with the wishes of many of the respondents themselves: the vast majority want to be permanently employed rather than live on benefits.

\section{REFERENCES}

Balás, Gábor et al (2011), A közcélú foglalkoztatás kibövülésének célzottsága, igénybevétele és hatása a tartós munkanélküliségre. Kutatási jelentés. Budapest, Budapest Intézet - Hétfa Elemző Központ

Bálint, Mónika - Köllő János (2008), “A gyermeknevelési támogatások munkaerőpiaci hatásai", Esély No. 1, pp. 3-27.

Bartus, Tamás (2007), "Városok elérhetősége: tények, okok, következmények", Kormányzás, Közpénzügyek, Szabályozás Vol. 2, No. 2, pp. 291-307.

Bódis, Lajos (2002), "A multinacionális tömeggyártó üzemek és az állami munkaközvetítés”, Szociológiai Szemle No. 1, pp. 21-45.

Bódis, Lajos - Galasi Péter - John Micklewright - Nagy Gyula (2005), Munkanélküliellátás és hatásvizsgálatai Magyarországon, KTI könyvek, Budapest, MTA-KTI

Csoba, Judit (2010), "A közfoglalkoztatás régi-új rendszere. Útközben az "Út a munkához" programban”, Esély No. 1, pp. 4-24.

Durst, Judit (2002), "Innen az ember jobb, hogyha meg is szabadul". Megélhetési stratégiák egy kisfalusi cigány közösségben”, Esély No. 4, pp. 99-121.

Durst, Judit (2006), Kirekesztettség és gyermekvállalás. A romák termékenységének változása néhány "gettósodó" aprófaluban (1970-2004). PhD. disszertáció, Budapest, BCE

Erdős, Kamill (1958), A magyarországi cigányság. Néprajzi Közlemények III., Budapest

G. Fekete, Éva (2005), “Cigányok a Cserehát-Hernád-Bódva vidéken. Tájegységi elemzés," in: Baranyi, Béla, ed., Roma szegregációs folyamatok a csereháti és délbaranyai kistérségekben, Budapest, Gondolat - MTA ENKI, pp. 53-83.

Fleck, Gábor - Virág, Tünde (1998), "Hagyomány vagy alkalmazkodás, avagy Gilvánfa kívül-belül”, Szociológiai Szemle No.1, pp. 67-92.

Formoso, Bernard (2000), "Cigányok és letelepültek," in: Prónai, Csaba, ed., Cigányok Európában 1.: Nyugat-Európa, Budapest, Új Mandátum Kiadó

Havas, Gábor(1982), "Foglalkozásváltási stratégiák különbözőcigány közösségekben”, in: Andor, Mihály ed., Cigányvizsgálatok, Budapest, Múvelődéskutató Intézet, pp. 181-202.

Havas, Gábor (1999), “A kistelepülések és a romák”, in: Glatz, Ferenc, ed., A cigányok Magyarországon, Magyarország az ezredfordulón. Budapest, MTA

Havasi, Éva (2010), “Jövedelmi helyzet, megélhetési viszonyok a mély szegénységben 
élők körében”, in: Kóczé, Angéla, ed., Nehéz sorsú asszonyok feketén fehéren, Budapest, MTA ENKI, pp. 19-50.

Horváth, Kata (2001), "Cigány munka" - "Gádzsó munka"”, in: Ando, György - Eperjessy Ernő - Grin Igor - Krupa András eds., A nemzetiségi kultúrák az ezredfordulón (Esélyek, lehetöségek, kihívások) Békéscsaba-Budapest, Magyar Néprajzi Társaság, pp. 401-413.

Horváth, Kata (2002), "Gyertek ki nálunk, hogy jobban megismerjük egymást!" Epizódok egy falusi magyar cigányközösség életéből”, in: Kovács, Nóra - Szarka, László eds., Tér és terep. Tanulmányok az etnicitás és az identitás kérdésköréböl, Budapest, Akadémiai Kiadó, pp. 241-325.

Husz, Ildikó (2011), “Alacsony végzettség - sok gyerek? A magas termékenység néhány területi és etnikai aspektusáról”, Demográfia No. 2. pp. 5-22.

Kemény, István ed. (2000), A romák/cigányok és a láthatatlan gazdaság, Budapest, Osiris - MTA Kisebbségkutató Mủhely

Kertesi, Gábor (2000), "Ingázás a falusi Magyarországon. Egy megoldatlan probléma”, Közgazdasági Szemle, Vol. 47, pp. 775-798.

Kertesi, Gábor (2005), A társadalom peremén. Romák a munkaeröpiacon és az iskolában, Budapest, Osiris Kiadó

Kertesi, Gábor - Köllő, János (2004), “A 2001. évi minimálbér-emelés foglalkoztatási következményei” Közgazdasági Szemle Vol. 51, No.4, pp. 293-324.

Kóczé, Angéla (2010), “Etnicitás, gender és a szegénység összefonódásának megnyilvánulásai”, in: Kóczé, Angéla, ed., Nehéz sorsú asszonyok feketén fehéren, Budapest, MTA ENKI, pp. 81-95.

Kopasz, Marianna (2007), A vállalkozói potenciál területi különbségeinek magyarázata, Budapest, Akadémiai Kiadó

Köllő, János (1997), “A napi ingázás feltételei és a helyi munkanélküliség Magyarországon: számítások és számpéldák”, Esély No. 2. pp. 33-61.

Köllő, János (2009), A pálya szélén. Iskolázatlan munkanélküliek a posztszocialista gazdaságban, Budapest, Osiris Kiadó

KSH Stadat: Statistical database, www.ksh.hu

KSH (2010), Demográfiai Évkönyv 2010

Ladányi, János - Szelényi Iván (2004), A kirekesztettség változó formái, Budapest, Napvilág Kiadó (in English: Ladányi, János - Szelényi Iván (2006), Patterns of Exclusion: Constructing Gypsy Ethnicity and the Making of an Underclass in Transitional Societies of Europe, East European Monographs, NO. DCLXXVI., New York, Boulder

Lewis, Oscar (1961), The Children of Sanchez: Autobiography of a Mexican Family, New York, Random House

Loury, Glenn C. (2006), A faji egyenlötlenségek anatómiája, Budapest, Nemzeti Tankönyvkiadó

Messing, Vera - Molnár, Emília (2011), "Válaszok a pénztelenségre: szegény cigány és nem cigány családok megélhetési stratégiái”, Esély No. 1, pp. 53-80.

Okely, Judith (1991), “Szimbolikus határok”, Café Bábel No. 1, pp. 37-55.

Romano Rácz, Sándor (2008), Cigány sor, Budapest, Osiris 
Stewart, Michael (1994), Daltestvérek, Budapest, T-Twins Kiadó - MTA Szociológiai Intézet - Max Weber Alapítvány

Szuhay, Péter (1999), "Foglalkozási és megélhetési stratégiák a magyarországi cigányok körében”, in: Glatz, Ferenc, ed., A cigányok Magyarországon, Magyarország az ezredfordulón, Budapest, MTA, pp. 139-161.

Szuhay, Péter (2005), “(Utó)parasztosodási törekvések a szendrőládi romák körében”, in: Schwarcz, Gyöngyi - Szarvas, Zsuzsa - Szilágyi, Miklós, eds., Utóparaszti hagyományok és modernizációs törekvések a magyar vidéken, Budapest, MTA Néprajzi Kutatóintézet - MTA Társadalomkutató Központ

Tardos, Katalin (2005), “Az önkormányzati munkaerőpiac és a roma munkanélküliek”, in: Neményi, Mária - Szalai, Júlia, eds., Kisebbségek kisebbsége, Budapest, Új Mandátum Kiadó, pp. 128-151.

Tóth, Pál (1997), “A falusi cigányság és az informális szektor”, Magyar Tudomány, CIV. Kötet (Új folyam XLII. kötet), No. 6, pp. 690-697.

Virág, Tünde (2008), "Változó gazdasági-társadalmi kapcsolatok egy cigányok lakta faluban”, Szociológiai Szemle No.1, pp. 60-77. 